Review

\title{
Soil and Water Conservation Strategies in Cape Verde (Cabo Verde in Portuguese) and Their Impacts on Livelihoods: An Overview from the Ribeira Seca Watershed
}

\author{
Isaurinda Baptista ${ }^{1,2, *}$, Luuk Fleskens ${ }^{2,3}$, Coen Ritsema ${ }^{2}$, António Querido ${ }^{4}$, Jacques Tavares ${ }^{1}$, \\ António D. Ferreira ${ }^{5}$, Eduardo A. Reis ${ }^{1}$, Samuel Gomes ${ }^{1}$ and Anabela Varela ${ }^{6}$ \\ 1 Instituto Nacional de Investigação e Desenvolvimento Agrário (INIDA), CP 84, 7600 Praia, \\ Cape Verde; E-Mails: jacques.tavares@gmail.com (J.T.); amarildo.reis@inida.gov.cv (E.A.R.); \\ Samuel.Gomes@inida.gov.cv (S.G.) \\ 2 Soil Physics and Land Management group, Wageningen University (WUR), 6700 AA Wageningen, \\ The Netherlands; E-Mails: luuk.fleskens@wur.nl (L.F.); Coen.Ritsema@wur.nl (C.R.) \\ 3 Sustainability Research Institute, School of Earth and Environment, University of Leeds, \\ Leeds LS2 9JT, UK \\ 4 Environment, Energy \& Natural Disaster Prevention Unit, Office of United Nations, PO Box 62, \\ 7600 Praia, Cape Verde; E-Mail: antonio.querido@cv.jo.un.org \\ 5 CERNAS, Escola Superior Agrária de Coimbra, Bencanta, P-3040-316 Coimbra, Portugal; \\ E-Mail: aferreira@esac.pt \\ 6 Direcção geral de Agricultura e Desenvolvimento Rural (DGADR/DSER), CP 115, 7600 Praia, \\ Cape Verde; E-Mail: Anabela.Varela@mdr.gov.cv \\ * Author to whom correspondence should be addressed; E-Mail: isaurinda.baptista@wur.nl or \\ ibaptista@inida.gov.cv; Tel.: +238-993-8308 or+238-271-1127; Fax: +238-271-1133.
}

Academic Editor: Katharina Helming

Received: 28 August 2014 / Accepted: 22 December 2014 / Published: 14 January 2015

\begin{abstract}
Severe land degradation has strongly affected both people's livelihood and the environment in Cape Verde (Cabo Verde in Portuguese), a natural resource poor country. Despite the enormous investment in soil and water conservation measures (SWC or SLM), which are visible throughout the landscape, and the recognition of their benefits, their biophysical and socioeconomic impacts have been poorly assessed and scientifically documented. This paper contributes to filling this gap, by bringing together insights from literature and policy review, field survey and participatory assessment in the Ribeira Seca Watershed through a concerted approach devised by the DESIRE project (the "Desire
\end{abstract}


approach"). Specifically, we analyze government strategies towards building resilience against the harsh conditions, analyze the state of land degradation and its drivers, survey and map the existing SWC measures, and assess their effectiveness against land degradation, on crop yield and people's livelihood. We infer that the relative success of Cape Verde in tackling desertification and rural poverty owes to an integrated governance strategy that comprises raising awareness, institutional framework development, financial resource allocation, capacity building, and active participation of rural communities. We recommend that specific, scientific-based monitoring and assessment studies be carried out on the biophysical and socioeconomic impact of SLM and that the "Desire approach" be scaled-up to other watersheds in the country.

Keywords: land degradation; desertification; sustainable land management (SLM); livelihoods; poverty; governance; Cape Verde

\section{Introduction}

Cape Verde (Cabo Verde in Portuguese) is a small island country where a mix of climatic, geomorphologic, pedologic and human factors has resulted in widespread land degradation, with negative consequences for the livelihood of the population and its fragile environment [1,2]. The scarcity of natural resources and the weakness of the productive system make poverty a structural occurrence in the country.

Desertification, associated with the occurrence of extreme drought episodes, has been present throughout the country's history and has led to periods of food production deficit and famine, which have, in the past, caused thousands of deaths [1]. Following the last big famine in the late 1940's, the authorities took measures to eradicate famines from the country. The stabilization of the agricultural landscape with erosion control measures and the maintenance of sustainable yields became absolute priorities, not just for environmental protection, but also for survival. Since the country's independence in 1975, successive governments have focused their rural development policies on soil and water conservation (SWC) strategies to address desertification, water scarcity, and soil erosion, aiming to reconstruct the ecological potential and reduce poverty in rural areas [3]. This effort has completely changed the landscape to a level where SWC techniques can be found everywhere, with the exception of rock outcrops. This arduous task was performed in the interval of two generations, since the last big famine in 1948, and more assertively in 1975, using a set of SWC techniques [1] and a governance strategy involving the communities affected by the drought.

Several types of SWC measures were implemented throughout the country (i.e., terraces, half-moons, live barriers, contour rock walls, contour furrows, micro-catchments, check dams, runoff water collecting dams, water reservoirs, wells and afforestation with drought resistant species), aiming to hold the soil in place, the water in the soil and to combat desertification [1].

Current efforts to reverse and prevent land degradation focus on the concept of sustainable land management (SLM) which refers to the use of land resources to meet present needs without compromising the ability of future generations to meet their own needs [4,5]. SLM technologies include 
agronomic, vegetative, structural, and management measures to control land degradation and enhance productivity in the field [6]; thus, SWC measures implemented in Cape Verde promote the SLM concept. The increased efforts and financial resources allocated to the promotion of SLM calls for adequate monitoring and assessment (M\&A) of their impact and benefits. Nevertheless, SLM must reflect the human-environment interactions. This requires a system to systematically assess the impacts and benefits from SLM measures that remain a fundamental gap [7].

Investments in SLM measures are enormous at the national level have been huge, yet a clear overview of their extent and combined benefits in terms of agriculture productivity, conservation effectiveness, sustainability, and rural people's well-being, is still lacking. Information on past interventions is scattered and of little influence for new SLM activities. Implementation of the five-year research project, DESIRE (Desertification Mitigation and Remediation of Land: A global approach for local solutions), contributed to fill part of the gap for the Ribeira Seca Watershed (RSW), giving policy makers and implementing institutions a spatial overview of past and ongoing processes, so that they can plan future activities. The DESIRE project developed an approach for establishing SLM strategies in response to desertification, consisting of five steps: (1) establishing land degradation and SLM context and sustainability goals with stakeholders; (2) identifying, evaluating and selecting SLM strategies with stakeholders; (3) trialing and monitoring SLM strategies; (4) up-scaling SLM strategies; and (5) disseminating the knowledge gathered [8].

Even though consistent biophysical impact and cost-benefit studies of SWC measures are lacking, their contribution to the improvement of environmental conditions of the treated landscape is visible [9], making crop production possible, and consequently improving the livelihood of the rural people [1]. The implementation of SWC measures, particularly afforestation, has contributed to change the "lunar" aspect of the landscape to more pleasant and greener ones [10].

Since most of the rain-fed cropland is on steep slopes, the main concern has been to protect the hillsides from runoff and erosion caused by heavy rain events, while neglecting in-field agronomic measures that lead to sustainable productivity increase, such as soil cover and nutrient management. Rain-fed crop yields remain low, with maize grain yield not exceeding 1 ton $\cdot \mathrm{ha}^{-1}$. The low input farming system, dominated by continuous maize and beans intercropping still faces severe climate conditions, inadequate crop and land management practices, and land degradation.

In this paper, we aim to corroborate the importance of SLM measures for Cape Verde, the strategies undertaken to address desertification, and the impact of those measures on the environment and rural livelihood. More specifically, we analyze the government strategies towards building resistance against the harsh conditions and, based on the DESIRE approach and results within the RSW, we analyze the state of land degradation and its drivers, survey and map the existing SWC measures and assess their effectiveness against land degradation and impact on crop yield and livelihoods. We explore the governance aspects behind the relative success of Cape Verde in tackling desertification and rural poverty, to verify the replication potential in countries with similar adverse conditions. 


\section{Methods}

\subsection{Study Area}

\subsubsection{Cape Verde Natural Resource Endowment}

Rainfall and climate: Rainfall, as the dominant climate factor influencing land degradation, is extremely variable both in space and time and strongly influenced by elevation and topography. It results from the seasonal migration of the Inter-Tropical Convergence Zone (ITCZ) around the equator, which originates a single short wet season from July to October, and a long dry season from November to June $[11,12]$. The climate is predominantly semiarid. Rainfall typically ranges from 200 to over $650 \mathrm{~mm}$ in the upwind façade to less than $100 \mathrm{~mm}$ in the downwind side.

Water resources: Cape Verde has no permanent surface stock of fresh water, creating an almost total dependence on ground water supplies for domestic and agricultural use. Ground and superficial water resources are scarce as they depend on the erratic rainfall, susceptible to be lost to the sea. In an average rainfall year, about $20 \%\left(180\right.$ million $\left.\mathrm{m}^{3}\right)$ is lost through runoff; more than $50 \%$ is lost as evaporation; and only about $13 \%-17 \%$ recharges the aquifers [13]. About $60,000 \mathrm{~m}^{3} \cdot$ day $^{-1}$ are currently being pumped for irrigation, representing a serious overexploitation of available groundwater resources that contributes to soil and water salinization.

Soil resources and land management: Of the $4033 \mathrm{~km}^{2}$ of land surface that the country comprises, about $10 \%$ is cultivated. The soils are mainly of volcanic origin, medium to coarse textured, steep, low in organic matter and generally shallow. Of the arable surface $(41,000 \mathrm{ha}),>90 \%$ is used for rain-fed agriculture while about $5 \%$ is used for irrigated agriculture. About $23 \%$ of the country's surface is forested. Severe land degradation occurs in the whole country, in different ways and extent according to the physical characteristics of the islands. To prevent land degradation and to enable agriculture production, both structural and biological SWC and water harvesting measures have been implemented at a vast scale. For a more comprehensive review of the SWC and water harvesting measures, please refer to [1].

\subsubsection{Ribeira Seca Watershed: The Largest Watershed in Santiago Island}

Ribeira Seca Watershed (RSW) is located on the east-central side of the Santiago Island, between latitude $15^{\circ} 07^{\prime} 40^{\prime \prime} \mathrm{W}$ and longitude $23^{\circ} 32^{\prime} 05^{\prime \prime} \mathrm{W}$ (Figure 1). With a drainage area of about $72 \mathrm{~km}^{2}$, it represents 4 agro-climatic zones: semi-arid (49\%), arid (20\%), sub-humid (20\%), and humid (11\%) based on altitude, vegetation and relief [14].

The climate is characterized by a dry season that lasts 8-9 months (November to June) and a short, humid season of 3-4 months (July to October), with the humid period coinciding with high temperatures (Figure 2). Rainfall is extremely heterogeneous and its spatial-temporal distribution irregular.

The watershed has a maximum altitude of $1394 \mathrm{~m}$ and comprises seven sub-watersheds, characterized by steep slopes and annual precipitation that varies from $<200 \mathrm{~mm}$ downstream to $>650 \mathrm{~mm}$ upstream. The maximum average monthly temperature is $28.1^{\circ} \mathrm{C}$ and the minimum is $16.6^{\circ} \mathrm{C}$. The dominant land use is rain-fed agriculture, particularly the staple crops (maize and beans) and groundnut, occupying $83 \%$ of the area. The remaining area is used for: irrigated crops (sugarcane, fruits, vegetables, cassava and sweet potato) $5 \%$ (362 ha) and forest 4\% (251 ha). In addition; $1 \%$ are rock outcrops and $7 \%$ are 
built environment (Figure 3). Livestock keeping is an important activity in the watershed as most family farmers own animals, such as cows, goats, pigs, and chickens that often graze freely.

Figure 1. Location of the Ribeira Seca Watershed within Santiago Island and Cape Verde.

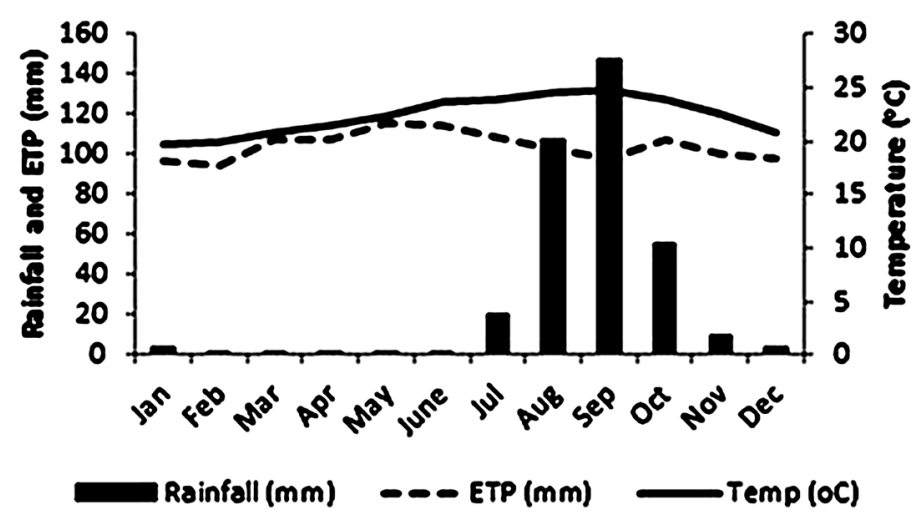

Figure 2. Mean annual rainfall distribution, evapo-transpiration and temperature for São Jorge Station (subhumid zone of Ribeira Seca Watershed): period 1973-2010.

The soils, mainly Regosols and Cambisols developed on basaltic substrate, are shallow and low in organic matter (OM), generally with low to medium fertility [15] and medium to coarse texture, and exhibit marked symptoms of degradation (i.e., rills and gullies). Deeper soils, i.e., Kastanozems with higher OM content and Vertisols, can be found on the plateaus (achadas) of less steep slopes. In the valley bottoms or ribeiras, Fluvisols are predominant and used for irrigated agriculture.

The Ribeira Seca Watershed has an estimated total population of about 15,000 people, with an even gender distribution. Of the women, $43 \%$ are head of household. The population is young, with $77 \%$ below 35 years old (of which $48 \%$ are below 15) and features an $83 \%$ literacy rate [16]. Poverty (people living on $<\$ 1.25$ a day [17]) affects $>60 \%$ of the population.

RSW was selected as the study area since it is the largest watershed of Santiago (the main agricultural island) that can be considered a reference for SWC works. 


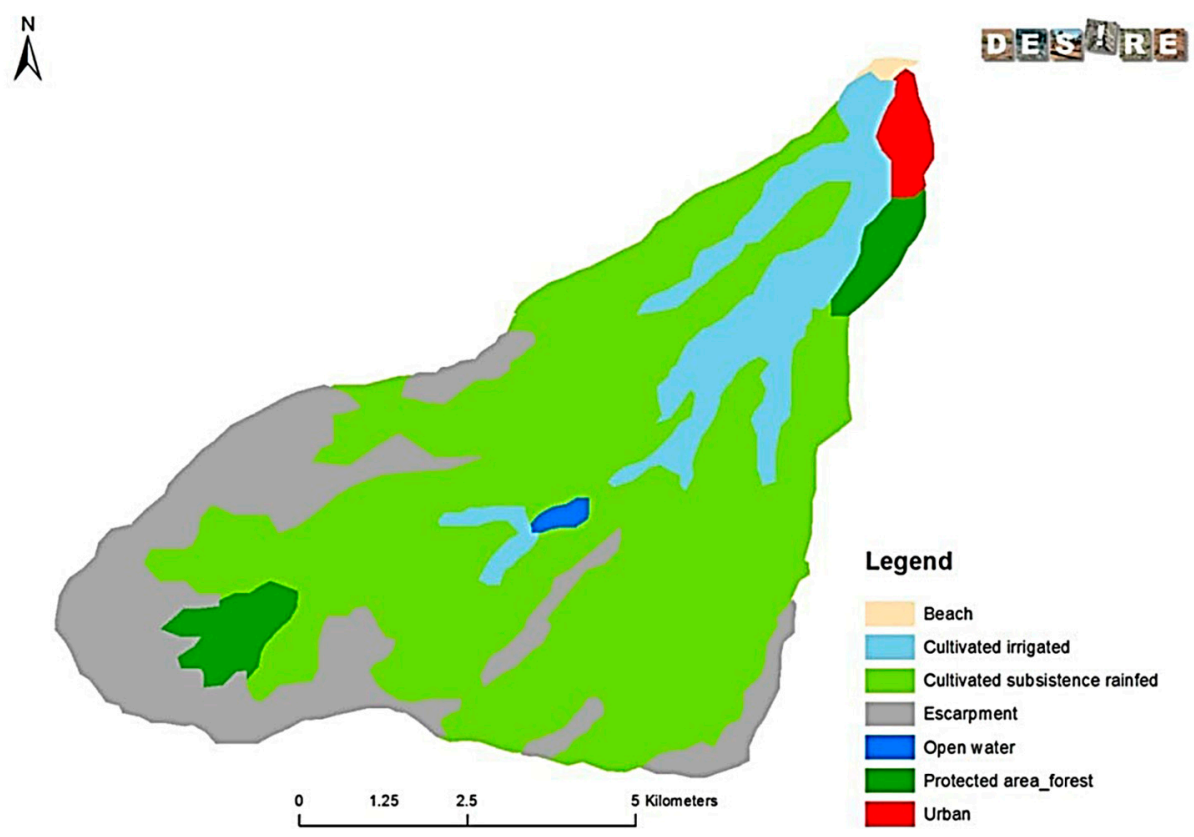

Figure 3. Map of land use types in the Ribeira Seca Watershed showing the dominance of rain-fed farming. Adapted from [18].

\subsection{Methodological Approach}

For this study, we used a mixed methods approach, consisting of literature and policy review, qualitative and quantitative field assessment and analysis of local and scientific knowledge. Tapping into local and expert opinion formed an important part of the methodology, both to triangulate results obtained using other methods, and because measurements and observations were not always possible.

An analyses of Government actions towards building resilience against the harsh drought conditions (Section 3) was conducted through national documents, such as strategic and action plans (i.e., the United Nations Conventions on Desertification-UNCCD, Biological Diversity-CBD, and Climate Change-UNFCC), policy regulations, and project implementation reports.

Assessment and mapping of land degradation status (drivers, types, and extent), existing SLM measures (types and extent), effectiveness of measures, and expert recommendation of conservation measures were carried out during implementation of the DESIRE project (2007-2012) using the "DESIRE approach" [8].

Land degradation and existing SLM measures were mapped using the WOCAT-LADA-DESIRE methodology and evaluated by applying WOCAT (World Overview of Conservation Approaches and Technologies) questionnaires on SLM technologies and approaches at local level [19]. WOCAT [20] offers a systematic methodology to assess both the institutional aspects (approaches) and practical implementation aspects (technologies) of SLM using expert questionnaires.

Detailed mapping coverage of the existing SWC measures was carried out using aerial photography [21]. The extent of land degradation was determined in \% on the mapping unit, based on the land use system as the basic unit of evaluation; while the degree of degradation refers to the intensity of the land degradation process, weighted against the extent for each map unit: Degree $\times$ Extent $(\%) / 100$.

The effectiveness of SLM measures was defined in terms of how much the measures reduce the degree, or prevent land degradation and was weighted against the extent for each mapping unit: Effectiveness $\times$ Extent $(\%) / 100$. 
Expert recommendation concerning interventions on how to address degradation was based on four groups: adaptation, prevention, mitigation and rehabilitation.

Stakeholders involvement in the project was accomplished through workshops following a standard approach developed for sharing of local knowledge $[6,10,22]$ and through WOCAT questionnaires that generated data for the mapping.

To assess the biophysical impact of selected SWC measures (terraces, vegetation barriers and rock walls - arretos) on dryland crop yield and soil quality, thirty six plots of $25 \mathrm{~m}^{2}$ were selected in farmers' fields, in three agroecological zones (arid, semiarid and subhumid), during the 2010 rainy season. In each plot, maize, bean and total biomass yield and soil quality parameters (nutrients, textures, organic matter, depth of top layer, etc.) were measured and compared to untreated plots using ANOVA and LSD, assuming other drivers (i.e., yield drivers) being constant. Results of other studies were also used as evidences of biophysical impact.

\section{Building Resilience to Challenge the Harsh Conditions: SLM Governance Factors}

\subsection{Eradicating Famine}

Cape Verde's history comprises remarkable events of crop failure and food insecurity that caused widespread starvation from the 16th to the 19th centuries, registering several famines and epidemics [1]. In the first half of the 20th century, six famines occurred, causing the starvation of more than 75,000 people [23]. The famine episodes were closely associated with the occurrence of extended periods of extreme drought. The last famine in 1947-1948 caused an almost 50\% reduction of the Cape Verde population, and Amaral [24] points out that in the Santiago Island alone the population decreased by $65 \%$.

Following the 1947-1948 famine, the colonial authorities took measures to mitigate the problem. The first was to employ people locally on the so-called Frentes de Alta Intensidade de Mão-de-Obra-FAIMO (High Intensity Labor Fronts) to implement SWC measures, such as terraces, dams, afforestation and irrigation infrastructure, to reduce erosion risk, conserve soil and retain water, thus stabilizing the agricultural landscape. FAIMO was a national program that ensured jobs for thousands of people in rural areas, particularly in dry years. A second measure was to expatriate people to other colonies to work in plantations. A third initiative was the installation of an agriculture technical school to guarantee technical know-how, dissemination and extension. These measures, together with large-scale emigration led to the eradication of famine from the country [1].

\subsection{Environmental Awareness and Actions}

The post-independence governments, facing successive dry years in the late 1970s and early 1980s, oriented their rural environmental actions towards combating desertification and land degradation by managing scarce financial resources, elaborating strategic instruments, creating proper institutional frameworks, setting policies and regulations and adhering to regional and international agreements. The establishment of an environmental restoration strategy was linked to political, cultural and economic objectives as the governments aimed to reduce rural poverty by creating jobs and reducing the rural exodus.

Financial resources management. From 1975 to late 1990s, Cape Verde received food aid which, in agreement with international donors, was internally commercialized to support development, with a 
large sum of the revenue channeled to SWC works and afforestation programs implemented through FAIMO $[1,25,26]$. The country also benefited from programs and projects with watershed development components such as: Community-based Project for the Development of Agriculture and Livestock (PRODAP/FIDA, 1993-1997), Watershed and Applied Research Development (WARD, 1993-1997), and the Millennium Challenge Account (MCA, 2007-2011), that contributed to implementing SWC works throughout the islands. Nowadays a large share of the Ministry of Rural Development's (MDR) budget is still being channeled to SWC through watershed planning and management projects, but the funds come from government loans for development.

National Instruments: The successive post-independence Governments defined instruments for the implementation of a national development strategy, aiming to mainstream environmental issues in the planning process to eradicate poverty and to promote sustainable development [27]. The most relevant ones are: The National Development Plans (PND); the Growth and Poverty Reduction Strategy (DECRP I: 2004-2007, II: 2008-2011, III: 2012-2016); the National Environment Action Plan (PANA II: 2004-2014); the National Program to Combat Poverty (PNLP 1996-2008); the National Adaptation Program of Action (NAPA 2008-2012); the Agricultural Development Strategic Plan (PEDA: 2004-2015); and the National Action Plan to Combat Desertification (PAN-LCD: 1998). PANA II, which promotes natural resources management, the use of efficient techniques, local participation in the sustainable use of natural resources, sustainable management of biodiversity and defines policies for food security, incorporates the objectives of PAN-LCD. For more than 10 years the UNCCD offered the outline of a global framework in the fight against desertification and Cape Verde has been positively evaluated for its implementation. Cape Verde is currently updating its PAN-LCD, aligning it with the UNCCD 10-year strategic plan (2008-2018).

Regional and international agreements: At regional level, Cape Verde is a member of CILSS (Permanent Interstate Committee for Drought Control), which is the regional organization for the formulation, analysis, coordination and harmonization of strategies and policies on food security and combating the effects of drought and desertification in the Sahelian countries. At the international level, the country is a member of the three United Nations Conventions (CBD, UNFCC, and UNCCD). The fact that Cape Verde was the first African country and the second in the world to ratify the UNCCD in 1995 [3] shows the strong commitment towards combating desertification, protecting the natural resources and fighting poverty in the country.

Institutional context. Combating land degradation through SWC measures constitutes the main pillar of the sustainable rural development strategy in Cape Verde. An institutional framework has been set up, adapted and strengthened through the years, to support both the current activities of rural development and UNCCD implementation. Currently, MDR is the coordinating institution and an umbrella organization of key departments such as the Direction General of Agriculture and Rural Development (DGADR); the National Institute of Agriculture Research and Development (INIDA), the National Institute of Rural Engineering and Forest (INERF/SONERF) and the National Institute of Water Resource Management (INGRH/ANAS). MDR collaborates with the Ministry of Environment, Housing and Territory Management (MAHOT) for crosscutting environmental issues.

Participatory approach. Stakeholders' participation in the post-independence implementation of SWC measures went through three major phases [3]: 
1. From 1975 to 1985 , participation of the population was achieved through FAIMO, which were institutionalized employment schemes that provided people with temporary paid work to alleviate their immediate household needs. The employment scheme and the top-down approach created their own dynamics: while successful in mobilizing the participation of land users, they led to a lack of perceived responsibility by landowners to maintain the structures [25], with consequences for the effectiveness of environmental conservation [26].

2. From 1985 to 1995 , in an attempt to change the concept of FAIMO by diversifying rural livelihood sources and introducing more participation of local people, there was some involvement of the stakeholders, particularly land users. However, it was not an effective participation since the approach did not emphasize participation as a process. Stakeholders' participation, as a process, needs to be supported by an approach that emphasizes empowerment, fairness, trust, and learning [28]. Thus, this can be considered a transitional phase to an effective stakeholders' participation.

3. From the late 1990's onwards, the ratification of the UNCCD harnessed the participation of local communities in drawing up a national action program to combat desertification (PAN-LCD). Since then, a full partnership with the population has been established, with community-based organizations playing a major role not only in implementing and maintaining SWC works, but also in contributing local knowledge and choosing the best local measures.

There is general consensus that success in combating land degradation and natural resource management can best be achieved with active involvement of affected populations in developing solutions, leveraging their knowledge and experiences and combining them with the knowledge of researchers and managers in all planning steps [10,29-34].

Also, taking the watershed as the planning unit, with full involvement of community associations and farmers, has enabled the capacity of local people to implement major rural engineering SWC works. Thus, SWC activities acquired new dynamics, moving from essentially work provision schemes to effective participation in both building and maintenance of SWC measures.

Stakeholders' awareness, training and capacity building. Since the 1990s an increasing attention was paid to awareness, training and capacity building of stakeholders on environmental conservation, which has positively influenced the success of SWC in the country. Stakeholders have become more conscious about the need for SWC and maintenance. Technical capacity building was crucial for executing engineering works. Currently, all environmental projects include awareness, training and capacity building activities for stakeholders.

As a result of these governance aspects, Cape Verde is currently recognized as a success case on transforming a harsh environment into a less hostile living environment and building resilience to absorb shocks from extreme drought periods, which no longer result in deaths due to famine or even starvation. From being one of the poorest countries in the world at independence in 1975 [23], Cape Verde graduated to a medium human development country in 2007 [35], and is currently pursuing a new development paradigm. New solutions have to be sought to provide food for a fast growing population, while intensifying soil productivity on highly degraded land and this should pass through the endorsement of SLM strategies. 


\section{Drivers of Land Degradation and Desertification}

Land degradation in Cape Verde, particularly in Ribeira Seca, results from a combination of climate, human and topographic factors.

Climatic drivers. Extended droughts have reduced vegetation cover, exposing bare land to erosion, while heavy rainfall events during the wet season generate high rates of runoff transporting enormous quantities of soil. Erosion by water (i.e., 43 and $23 \mathrm{t} \cdot \mathrm{ha}^{-1} \cdot \mathrm{yr}^{-1}$, at watershed and plot levels, respectively) seriously affects the quality of the environment, food security, sustainability and longevity of the limited arable land in the RSW [26,36].

Human drivers. In RSW, human activity exerts strong pressure on the limited land and water resources, contributing to land degradation in several ways [16]: (a) Inadequate agricultural practices such as intensive cultivation of steep slopes without adequate conservation measures and excessive weeding by hoe; (b) Overexploitation of the aquifers, through over-pumping of wells, which has resulted in sea water intrusion, leading to the salinization of soil and water in the valley bottom. Salinity has affected soil and water quality up to about $2.5 \mathrm{~km}$ from the coast into the valley; (c) Construction of the Poilão dam (2/3 of the way to the sea) has blocked the aquifer movement downstream and also contributed to salinization of the lands close to the sea; (d) rural poverty, leading to deforestation due to tree cuttings for domestic use as energy for cooking; and excessive grazing by animals.

Topographic and pedological factors. Rainfall is strongly influenced by elevation, with highest erosivity values at high elevations, coinciding with steep slopes and shallow soils, which make these areas susceptible to erosion [12]. Despite the natural fertility of the soils due to their volcanic nature, intensive cultivation without replenishment of soil nutrients has resulted in the decline of fertility in the dryland soils. Since farmers do not apply any fertilizers on dryland soils, the only source of nutrients for the maize crop comes from the intercropped beans, which is not sustainable.

These driving forces place pressures on the land and have particular impacts at different levels. Cape Verde society and authorities have already produced some responses to those impacts and also seek better knowledge on how to respond. Decisions on responses are governed by a range of international, national and local policy regulations and agreements (see Section 3). Nongovernmental Organizations (NGOs), governments and civil society are working together in natural resource management to combat environmental degradation through reduction of poverty, as it is believed that, by reducing poverty, the pressure on natural resources will also decrease environmental degradation.

\section{Status of Land Resources and Management}

\subsection{Monitoring and Assessment in the Ribeira Seca Watershed}

Monitoring and assessment (M\&A) of SLM measures in Cape Verde are at an incipient stage, with few environmental projects containing these important components. Most projects lack a scientifically robust and consistent baseline, which is a key constraint to identifying priorities for action and monitoring their impact. This paper focuses on the implementation of the DESIRE project.

The bottom-up Desire approach to combat desertification advocated SLM based on inventories of local knowledge using an integrative participatory approach in close collaboration with local stakeholders, but with a sound scientific basis for effectiveness at various scales [8]. With the completion 
of the project, the data from RSW is part of a web-based harmonized information system [18] featuring the: socio-cultural, economic and environmental context; stakeholders goals and drivers of changes; status of land degradation and land management; identification, documentation and evaluation of SLM options; prioritization and selection of remediation options; field trials of SLM techniques with scientific and stakeholders' monitoring; biophysical and economic effects at field and regional scale; evaluation of options and recommendations; and strategy for disseminating recommendations at various levels. Given the DESIRE project's limited duration of five years, its methods, experiences, and know-how should be integrated into long-term programs (i.e., UNCCD) to ensure their continued use and ultimate effectiveness.

\subsection{Type, Degree, Extent and Trend of Land Degradation and Desertification Risk}

The RSW presents physical land degradation in various forms, degree, extent and rate (Figure 4a-d). The degree of degradation is light to moderate, possibly due to the large extent of conservation measures, covering $80 \%-100 \%$ of the cultivated rain-fed land. The main type of land degradation is water erosion, estimated to affect $26 \%-50 \%$ of the watershed area under subsistence rain-fed agriculture, manifesting first as loss of top soil, second as mass movement and third as gullies. Chemical degradation due to salinization in cultivated land under irrigation is also significant, affecting $11 \%-25 \%$ of the surface area. Wind erosion and biological degradation, associated to the loss of top soil and soil life, are less significant and affect $0 \%-10 \%$ of the RSW.

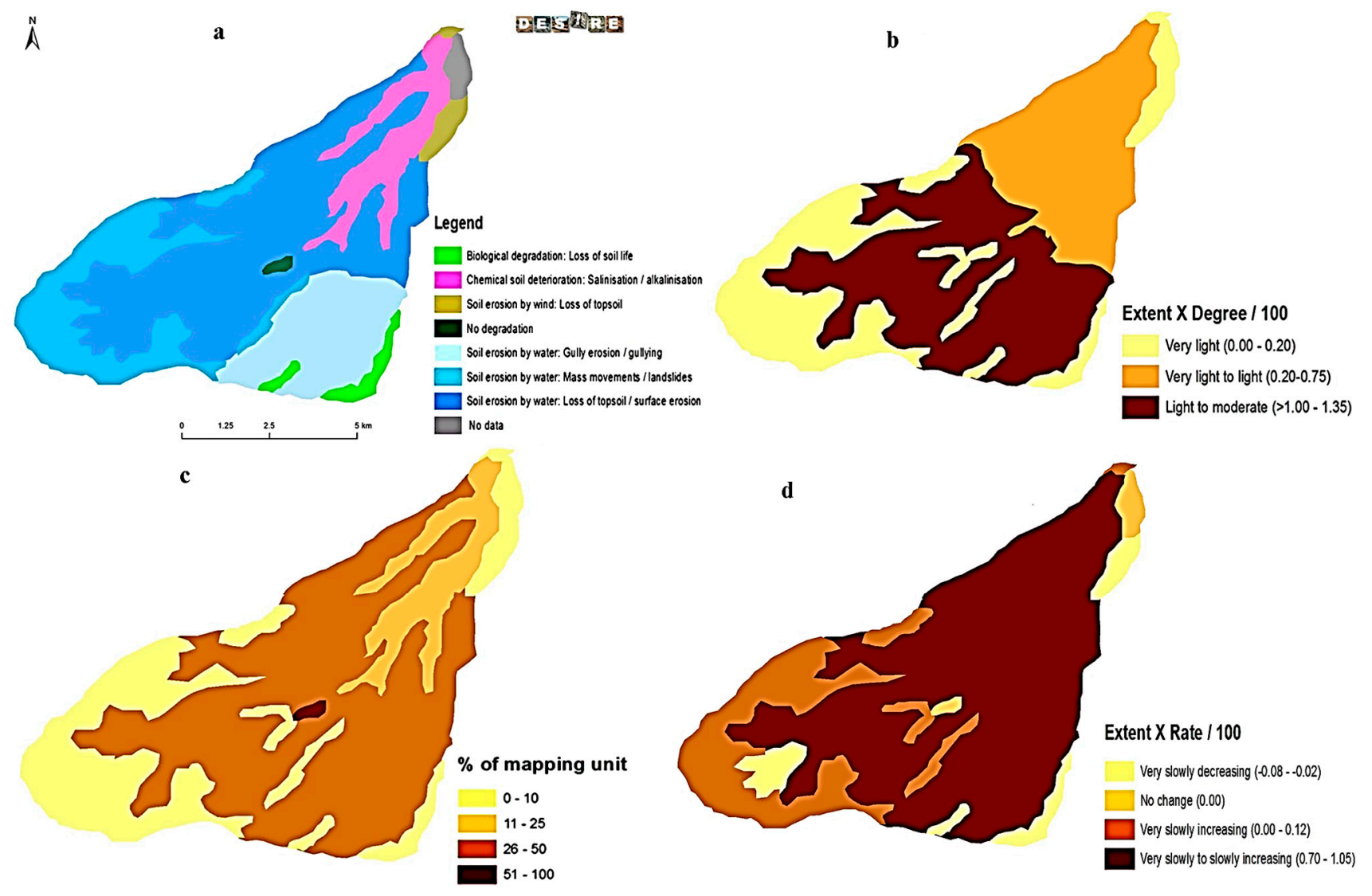

Figure 4. (a) Type, (b) degree, (c) extent and (d) rate of land degradation in the Ribeira Seca Watershed (RSW) on as the dominant type, moderate degree, and slight to moderate rate of degradation. Adapted from [18]. 
The rate of land degradation on the hillsides, as indicated by the trend over the recent past 10 -year period, was estimated as very slowly to slowly increasing.

\subsection{Magnitude of Soil Erosion}

Several attempts have been made to quantify erosion in the RSW both at plot $[2,26,37,38]$ and sub-watershed levels [39-43], with results indicating great spatial and temporal variability depending on slope, land-use, rainfall amount and intensity. Mean erosion rates $\left(\mathrm{t} \cdot \mathrm{ha}^{-1} \cdot \mathrm{yr}^{-1}\right)$ for traditional farming vary from 0.2 to 23 at plot level and from 0.1 to 43 at sub-watershed level under natural rainfall (Table 1). The smaller rates at plot level correspond to low slope areas and the larger to the steeper slopes. Given the large variability within the results, the high rates of erosion and the shallow soils on steep terrain, there is a need to carry out longer term assessments and to establish standard tolerable rates for Cape Verde hillsides, allowing policy makers to better plan SWC interventions.

Table 1. Mean rates of soil erosion in the Ribeira Seca Watershed at different scales and periods.

\begin{tabular}{|c|c|c|c|c|}
\hline Scale/Location/\% Slope & $\begin{array}{c}\text { Period of } \\
\text { Measurements }\end{array}$ & $\begin{array}{c}\text { Land Use/Conservation } \\
\text { Measure }\end{array}$ & $\begin{array}{l}\text { Magnitude } \\
\left(\mathrm{t} \cdot \mathbf{h a}^{-1} \cdot \mathbf{y r}^{-1}\right)\end{array}$ & Reference \\
\hline Sub-watershed: Seca (variable slopes) & 1985-1989 & $\begin{array}{l}\text { Mixed land-use/Check } \\
\text { dams }\end{array}$ & 4.66 & [39] \\
\hline $\begin{array}{l}\text { Sub-watershed: Longueira (variable slopes) } \\
\text { Sub-watershed/Grande/variable slopes } \\
\text { Sub-watershed: Godim/variable slopes }\end{array}$ & 2005-2009 & $\begin{array}{l}\text { Mixed land-use and } \\
\text { conservation measures }\end{array}$ & $\begin{array}{l}42.7 \\
1.57 \\
0.10\end{array}$ & [42] \\
\hline $\begin{array}{c}\text { Plot/O. Pequeno } / \leq 37 \\
\text { Plot } / \text { Serrado } / \leq 23 \\
\text { Plot } / \text { S. Jorge } / \leq 8\end{array}$ & 2011-2012 & Maize and beans & $\begin{array}{l}9.10(16.6) * \\
2.13(3.21) * \\
0.30(0.4) *\end{array}$ & [37] \\
\hline Plot/Godim)/50 & 1994-1996 & Maize and beans & $16.0(48) * *$ & [2] \\
\hline Plot/Godim/35-60 & & Maize and beans & $23(69) * *$ & {$[26]$} \\
\hline
\end{tabular}

* Maximum rates; ** total for period.

\subsection{Existing Land Management Measures}

Ribeira Seca is one of the watersheds in the country where most SWC measures, both structural and biological (vegetation), were implemented. Structural techniques comprise check dams, contour rock walls, contour furrows, micro catchments, terraces, water reservoirs and retaining dams (Figure 5a). Biological techniques consist of vegetation barriers with different species (i.e., Aloe vera, L. leucocephala, F. gigantean), pigeon pea cultivation and reforestation with drought-tolerant species. Vegetative measures, including tree/shrub cover, implemented to protect the steep hillsides, are most widespread and cover more than $80 \%$ of the watershed area (Figure 5b,c). Along the valley bottom and the steep water lines, about 200 check dams are present, contributing to decrease runoff rate and increase infiltration. The implementation of SWC techniques modifies landscape functions at different spatial scales [44] and in Cape Verde they have produced dramatic changes both at plot and watershed scales. Figure $6 \mathrm{a}-\mathrm{h}$ ) illustrates some relevant SWC measures in the watershed, some of which (i.e., afforestation and Aloe vera hedges) were documented as successful and promising conservation measures $[8,45]$. 
Recently, the government constructed large dams to collect and store runoff from the watersheds, with a total of five dams already built in the two largest islands. Ribeira Seca encloses one of the largest rainwater collecting dams built in the country, with a capacity of 1.2 million $\mathrm{m}^{3}$. The construction of this large piece of infrastructure (see Figure 6c) completely changed the surrounding landscape, allowing 188 ha of irrigated land. Drip irrigation was introduced in the 1990's as a more efficient and water saving irrigation system, and has been promoted since. In rain-fed areas in the downstream section of the watershed, large concrete water reservoirs were built to collect and stock rain water for supplementary irrigation, human and animal consumption $[1,3,16]$.

Afforestation (Figure 6h) with numerous drought-tolerant species is one of the key techniques to address land degradation and has increased from $<3000$ ha in 1975 to 92,000 ha in 2012 . It provides soil protection against erosion, fuel wood for cooking and animal feed, and enables better use of rainfall for increased crop productivity. Moreover, the large afforested area has conveyed more green color to the "lunar" aspect of the landscape. The total biomass production has reached 800,000 ton in Cape Verde and the total carbon sequestered in the biomass, 402,500 ton with Santiago Island contributing with $60 \%$ of the total [46].

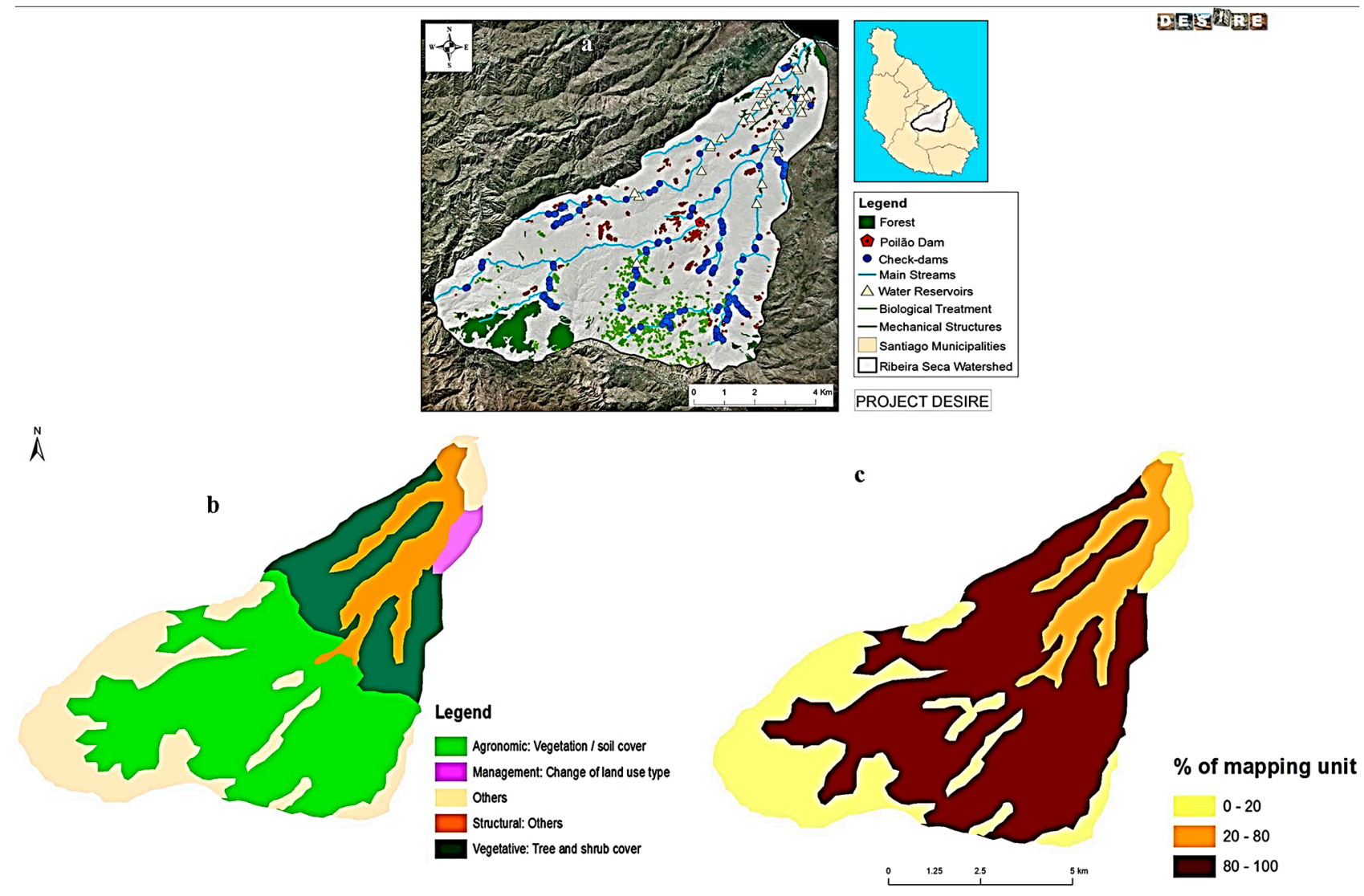

Figure 5. (a) Existing soil and water conservation measures (b) land conservation group measures and (c) extent as \% of mapping unit showing the importance of vegetation measures as the major conservation group at hillslope level. (b) and (c) adapted from [18]. 

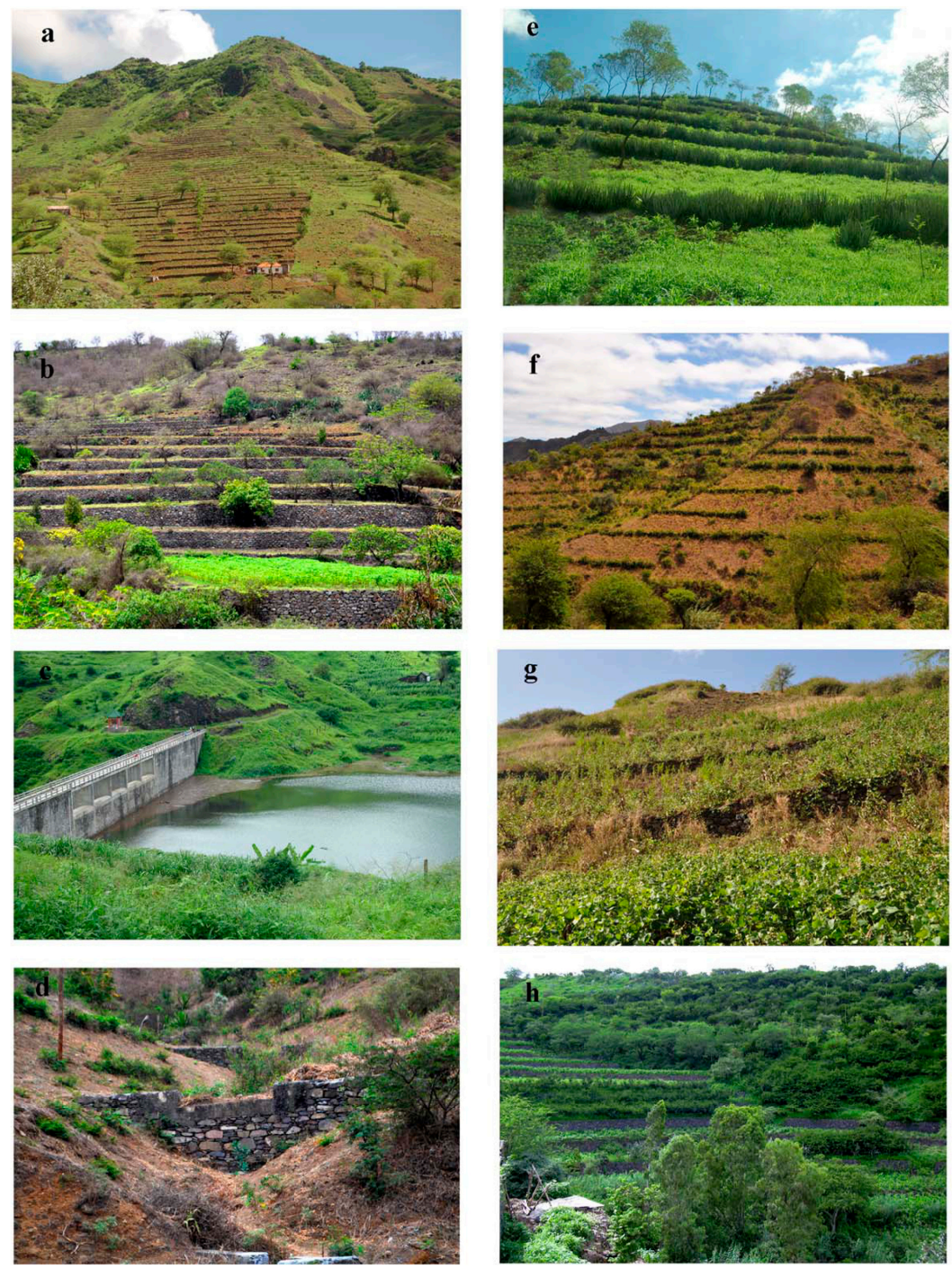

Figure 6. Vegetation and structural soil and water conservation measures in the Ribeira Seca Watershed: (a) contour rock walls; (b) terraces (São Jorge); (c) Water collecting dam (Poilão) during rainy season, d. check dams on water ways (Godim); (e) Aloe Vera barriers (São Jorge), (f) L. Leucocephala hedges (Godim); (g) Pigeon-pea on terraced fields; and (h) Afforestation with different species (Longueira Baixo).

\section{Effectiveness and Impact of SWC}

\subsection{Effectiveness for Slope Protection and Soil Cover}

Though the few studies carried out to evaluate the impact of SWC techniques on slope protection are not consistent, there is a consensus that the techniques implemented in the last half century played a positive role in the fight against land degradation $[1,10,26]$. The effectiveness of SWC measures refers to indications of how much or how well the measures reduce or prevent degradation [8]. The area of the watershed under rain-fed agriculture shows moderate to high effectiveness of the implemented measures (Figure 7a) with an increasing efficiency trend (Figure 7b). A small area, corresponding to the irrigated land at the valley bottom, shows low to very low conservation effectiveness with a slightly increasing trend. Although $>80 \%$ of the watershed benefits from conservation measures, their effectiveness trend 
shows the need for additional SLM measures, either as mitigation, prevention, rehabilitation or a combination, according to the land use type $[8,47]$. For the valley bottom affected by salinization, mitigation of the problem and prevention of further degradation are recommended; for the biological degradation with loss of soil life at high elevation, mitigation measures are recommended; for the severe loss of top soil in the upstream part of the watershed, a combination of mitigation, rehabilitation and rehabilitation measures is recommended; while downstream rehabilitation measures are recommended (Figure 7c).

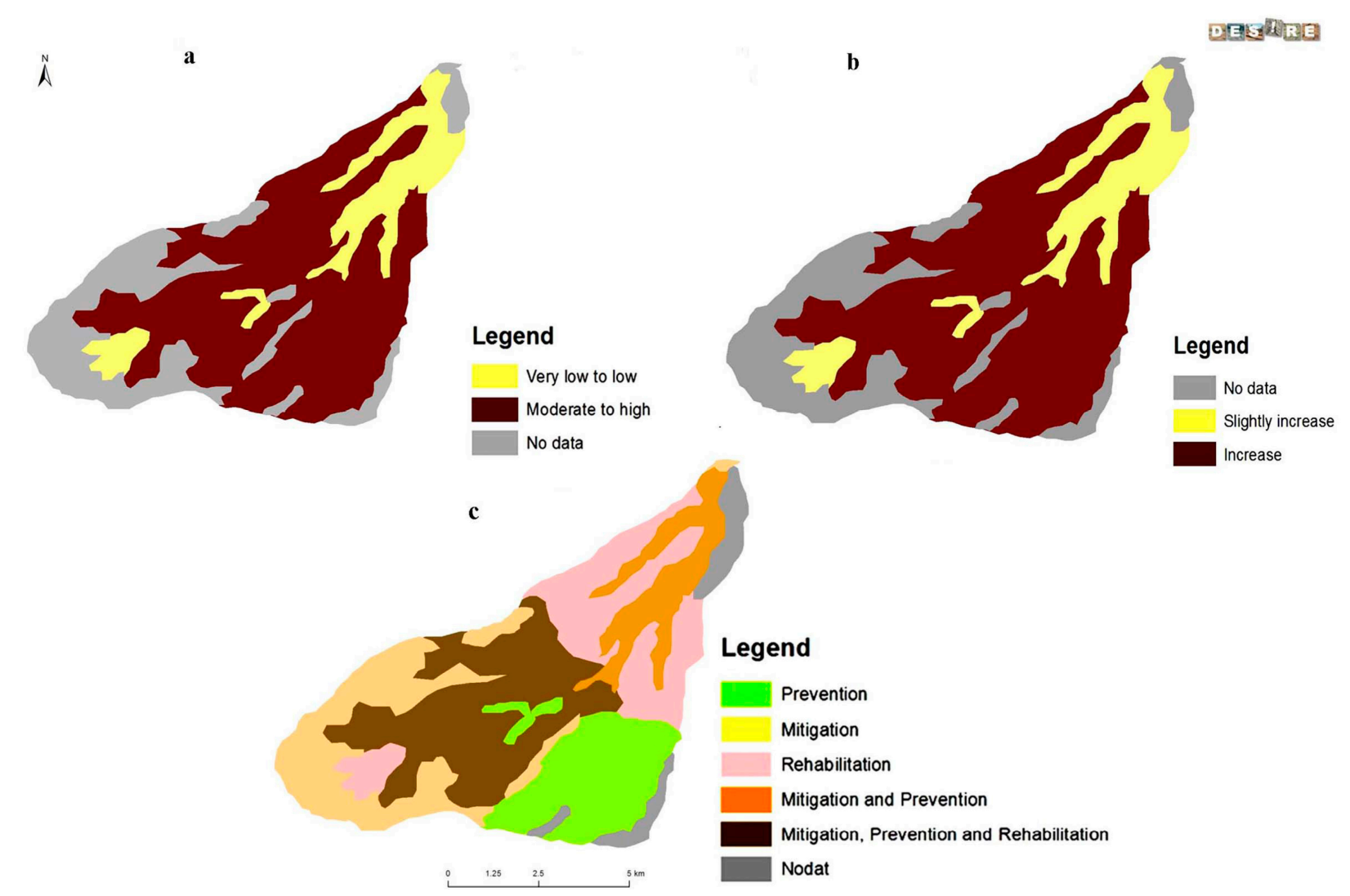

Figure 7. Effectiveness of conservation measures in the Ribeira Seca Watershed, weighted by area, evidencing: (a) the moderate to high effectiveness of the implemented measures at slope level, (b) the increasing conservation efficiency trend on the slopes and (c) expert recommendation on measures. Adapted from [18].

At hillslope level, Ferreira [1] and colleagues reported a positive effect of different SWC techniques (i.e., vegetation strips, afforestation, terraces, contour stone walls and vegetation strips) on parameters like soil compaction, erosion index, rock outcrops and stone, organic matter, vegetation cover and soil accumulation. Smolikowski [2] and colleagues showed the effectiveness and the importance of vegetation barriers and mulch against water erosion when compared with traditional cropping practices (maize and beans), while Querido [26] reported that the use of 1.5 ton/ha of mulch reduced soil erosion by up to $95 \%$ and significantly increased infiltration. Baptista [37] and colleagues also reported up to $100 \%$ reduction in soil loss from steep dryland hillsides with a combination of crop residue mulching, pigeon-pea hedges and organic amendments. 
Agronomic trials of pigeon-pea runoff barriers under the DESIRE project [48] resulted in positive ecological impact such as $28 \%$ reduction in area with erosion rates $>10 \mathrm{t} \cdot \mathrm{ha}^{-1} \cdot \mathrm{yr}^{-1}$ and $>20 \%$ increase in both water availability and ground water recharge. As off-site impact, $>20 \%$ reduction in flooding and $20 \%$ less stream discharge were also reported. However, these are experimental results that have not been applied at larger scale.

\subsection{Impact on Crop Yield}

Impact studies of techniques on dryland crop productivity carried out by INIDA have turned out inconsistent through the years, depending on yearly rainfall and agro-ecological zone. In 2005, a year considered of deficient rainfall both in amount and distribution, a significant increase of $87 \%$ was registered for maize grain and biomass yield for contour stone walls when compared to non-treated plots, assuming other yield drivers constant [49]. However, this significant increase was only verified in the semiarid agro-ecological zones and not in humid, sub-humid or arid zones.

Table 2. Some indicators of biophysical impact of pigeon-pea technology in the Ribeira Seca Watershed (RSW) at field scale. Source: [10,48].

\begin{tabular}{llll}
\hline Parameter & Before Technology & Year 1 & Year 2 \\
\hline Soil cover $(\%)$ & $<1$ & 35 & $48-87$ \\
Dry organic mulch $(\%)$ & $<5$ & 31 & 60 \\
Grain yield $\left(\mathrm{t} \cdot \mathrm{ha}^{-1}\right)$ & $<0.2$ & 1.9 & 1.8 \\
Biomass $(\%$ increase) & & & 115 \\
\hline
\end{tabular}

On the other hand, in 2010, a year of good rainfall amount and distribution, none of the assessed SWC measures (terraces, vegetation barriers and contour rock walls) resulted in a significant increase in maize, bean or biomass yield, in any of the three agro- ecological zones, when compared with untreated field plots. Likewise, no significant effect on soil quality parameters such as nutrients availability, depth of topsoil and organic matter was registered. The absence of an increase in yield could be explained by the positive water balance observed during the growing period, indicating that soil moisture was not limiting crop yield. However, since overall mean crop yields were low ( 0.6 and $0.3 \mathrm{t} \cdot \mathrm{ha}^{-1}$ for maize and bean, respectively), other factors such as low soil fertility (i.e., $\mathrm{N}$ and $\mathrm{OM}$ content) might also have influenced crop development and yield [50].

Other researchers $[10,48]$ reported increased biophysical impact of the implemented pigeon-pea (Cajanus cajan) technology in RSW, at field scale trials, compared to without implementation (Table 2). Soil cover increased up to $87 \%$, dry mulch by $60 \%$, grain yield by $89 \%$, and biomass production by $115 \%$ after the second year of implementation.

To improve the quality of biophysical impact assessment of SWC measures on crop yield, there is a need for more systematic and longer-term evaluation, allowing the establishment of a more consistent trend based on rainfall amount and distribution, agro-ecological zone and soils characteristics. 


\section{Sustainable Rural Livelihood}

\subsection{Livelihood Approach to Soil and Water Conservation}

The SWC measures implemented contributed to the improvement of the economic and environmental conditions of the treated lands in Cape Verde by making crop production possible, and consequently improving the livelihood of the people. The SLM measures implemented in the RSW have, to a great extent, imparted resilience to the agro-ecosystems, making them able to resist droughts and land degradation as evidenced by the high effectiveness of the measures, greener landscape, more water available, slight to moderate degree of degradation and moderate risk of desertification. These positive aspects contribute to people's well-being as evidenced by farmers' testimonies showing satisfaction, for example, with the pigeon-pea technology that lead to high yield and better soil cover, with positive impacts on soil conservation, human and animal feed [10]. Evaluation of the global scenario for food production [48] shows that the pigeon-pea technology can achieve very significant yield increases, both per area $\left(2568 \mathrm{~kg} \cdot \mathrm{ha}^{-1}\right)$ and per capita $(1218 \mathrm{~kg})$, thus, reducing poverty level. Pigeon-pea technology also resulted in 50\% increase in production area and 50\% reduction in production risk in RSW.

In addition, surface runoff water stored in the Poilão dam $\left(1.714 \mathrm{~m}^{3}\right)$ is used for irrigation of 188 ha of land, allowing farmers to increase yield and diversity their livelihood sources of income [51].

Though benefits of SWC measures are in line with the sustainable rural livelihoods framework [52], dryland agriculture sustainability as a whole may be questioned as unsuitable conditions such as high rates of soil erosion in many parts of the country, low rain-fed productivity, inadequate agricultural practices and high incidence of rural poverty $(>60 \%)$, still occur.

\subsection{Cultural Value of Rain-Fed Crops}

Maize was introduced in Cape Verde from Brazil in the XVI century and evolved as the predominant dryland crop and the preferred staple food for the population [11]. Despite the low yields (300-700 kg maize grain per ha) and frequent crop failure, farmers routinely plant maize every year, regardless of the economic loss and environmental degradation arising from this agricultural activity. Land degradation has been widely associated with dryland farming practices [10,37] as the conventional maize cultivation is practiced on steep lands without SWC measures, is excessively hoe-weeded, has low soil cover and thus leads to high soil erosion rates.

Maize is at the basis of local people diet and farmers are reluctant to cultivate other cereals. Several attempts were made to introduce crops like sorghum and quinoa that research proved to be better suited for the short rainy season, but the crops were not accepted by local people. Maize and beans production in dryland does not contribute more than $5 \%$ to rural household revenues, and some families incur net costs for their cultivation [53]. Moreover, the market price of imported maize and beans is lower than local production cost. Thus, the importance of dryland crops like maize and beans is more due to their cultural than economic value, making them unlikely to be substituted for crops potentially more economically valuable or that promote SLM. 


\subsection{Importance of Dryland Production for Rural Family Food Security}

Rain-fed maize production in Cape Verde does not cover more than $10 \%-15 \%$ of consumption in a normal rainfall year [54]; nonetheless, it plays a crucial role in guaranteeing food security of the rural families. Firstly, it provides food grain (maize and beans) for family consumption so that in years of "good" rainfall families do not have to buy these food items for the whole year. Secondly, it provides crop biomass and stubble grazing, so the families keeping livestock do not spend money buying animal feed. Animals like goats, cattle, and pigs contribute up to $47 \%$ to the rural household income as well as food for the families [53]. Thirdly, rain-fed production guarantees maize and bean seeds for subsequent years, so that farmers do not have to buy them.

\section{Policy Oriented Recommendations}

Cape Verde's government should reinforce its policy regarding SLM practices, as they have numerous environmental, economic, and social benefits, reaching far beyond their potential to reduce land degradation and desertification. SLM also addresses global concerns such as water scarcity, resource-use efficiency, food security, poverty relief, climate change, and biodiversity conservation [55]. These multiple benefits justify investments in SLM and may require funding schemes from different sources, especially when involving small-holder farmers and poor people.

The huge annual spending on implementation of SLM calls for concerted efforts to standardize documentation and evaluation. New efforts towards SLM should build on existing knowledge either from within the country or from similar environments elsewhere. Identifying and assessing existent knowledge on SLM and making it widely available needs a harmonized methodology for comprehensive data collection, knowledge management, and dissemination, such as the DESIRE approach applied in the RSW.

The DESIRE experience in Cape Verde emphasized the importance of a close partnership between researchers and local stakeholders in developing and evaluating SLM options to meet local needs and priorities. Stakeholders' active involvement in the project has resulted in the application of the SLM measures tested. It is important to consider local knowledge and traditional approaches to land management together with the latest research tools (i.e., WOCAT-LADA-DESIRE mapping, DESIRE expert system, decision support tool), and to combine perceptions from both sources. Such tools can be used in reporting to UNCCD, thus contributing to the implementation of the convention in the country.

\section{Conclusions}

(Cabo Verde in Portuguese) has long recognized land degradation and desertification as major threats to its environment with direct impact on human well-being and social welfare. The country moved from experiencing regular crop failure and starvation to being a success case on managing a harsh environment and scarce natural resources to provide food security and improve the livelihoods of local inhabitants. Quoting the Minister of Rural Development (Mrs. Eva Ortet), allusive to the Desertification day, 2014, "Cape Verde has successfully faced its limitations".

The dual orientation of rural development policies towards combating desertification and reducing poverty based on massive implementation of SWC measures has resulted in building resilience to extreme drought periods. 
The country's relative success in managing harsh conditions can be attributed to "good governance" in combating land degradation and desertification as evidenced by the positive evaluation of the UNCCD and DESIRE project implementation. Good governance here refers to: a responsible handling of funds, an adequate framework and institutional setup, an appropriate set of instruments, the inclusion of civil society, and capacity building at national and international levels.

Although the positive impact of the implemented SWC measures on the environment, economy, food production, livelihood and combating land degradation in the country is generally acclaimed, monitoring and assessment of biophysical and socioeconomic impacts of SLM remain incipient, poorly quantified and documented, being restricted to a few isolated studies with limited scope.

There is a need for better integration of biophysical and socioeconomic aspects of SLM through a robust scientific framework. As an example of a standardized and harmonized knowledge management system, the DESIRE methodology provided a key pillar for informed decision-making at different scales by: giving SLM measures a sound scientific basis; improving indicators; assessing and developing promising SLM strategies with stakeholders; evaluating SLM measures on regional scale; and disseminating results, guidance and decision support tools suitable for all relevant stakeholders. DESIRE's methods, experiences, and know-how should be integrated into long-term programs (i.e., UNCCD) to ensure their continued use and ultimate effectiveness. Joint commitment of all institutions, projects, and actors involved in SLM is needed to build a harmonized knowledge system for scaling up SLM.

\section{Acknowledgments}

We are grateful to the Netherlands Universities Foundation for International Cooperation (NUFFIC) for funding the $\mathrm{PhD}$ project (through the NFP-PhD-10/132), the Instituto Nacional de Investigação e Desenvolvimento Agrário of Cabo Verde (INIDA) for providing logistic facilities for field work, and the DESIRE project Desertification Mitigation and Remediation of Land-A Global Approach for Local Solutions (under EF6 - contract \# 037046 GOCE) for providing assessment data for the study and partial funds for the field work. We are particularly thankful to the Cape Verde DESIRE team for carrying out most of the field assessment and ISRIC (International Soil Reference and Water Conservation) team for producing the land degradation and conservation maps. We are grateful to the five anonymous reviewers for their valuable comments to the initial version of the manuscript.

\section{Author Contributions}

Isaurinda Baptista, the lead author of the manuscript, conducted the majority of the literature review, developed the concept and structure of the paper and wrote the first drafts using various input and editing suggestions from co-authors. Luuk Fleskens revised the first draft of the manuscript and provided a better logical structure and fundamental concepts. Coen Ritsema revised the second and third draft of the paper and provided supporting evidences. António Querido contributed to the conception of the manuscript and through the editorial process. Jacques Tavares and Eduardo Reis carried out most of the field assessments for the elaboration of the various land degradation and conservation maps. António Ferreira provided supporting information and contributed as well through the editorial process. Samuel Gomes provided literature review data for Section 3; Anabela Varela carried out biophysical field assessment related to impact of SWC techniques on crop yield and soil quality. 


\section{Conflict of Interest}

The authors declare no conflict of interest.

\section{References}

1. Ferreira, A.D.F.; Tavares, J.; Baptista, I.; Coelho, C.O.A.; Reis, A.; Varela, L.; Bentub, J. Efficiency of overland and erosion mitigation techniques at Ribeira Seca, Santiago Island, Cape Verde. In Overland Flow and Surface Runoff; Hydrological Science and Engineering Book Series; Wong, T.S.W., Ed.; Nova Science Publishers, Inc.: Singapore, 2013; pp. 113-135.

2. Smolikowski, B.; Puig, H.; Roose, E. Influence of soil protection techniques on runoff, erosion and plant production on semi-arid hillsides of Cabo Verde. Agric. Ecosyst. Environ. 2001, 87, 67-80.

3. Direcção Geral do Ambiente (DGA). PANAII-Segundo Plano de Acção Nacional para o Ambiente (2004-2014); Ministério do Ambiente, Agricultura e Pescas: Praia, Cape Verde, 2004

4. Cowie, A.L.; Penman, T.D.; Gorissen, L.; Winslow, M.D.; Lehmann, J.; Tyrrell, T.D.; Twomlow, S.; Wilkes, A.; Lal, R.; Jones, J.W.; et al. Towards sustainable land management in the drylands: Scientific connections in monitoring and assessing dryland degradation, climate change and biodiversity. Land Degrad. Dev. 2011, 22, 248-260.

5. World Overview of Conservation Approaches and Technologies (WOCAT). Where the Land is Greener-Case Studies and Analysis of Soil and Water Conservation Initiatives Worldwide; Liniger, H.P., Critchley, W., Eds.; Technical Centre for Agriculture and Rural Cooperation (CTA): Wageningen, The Netherlands; Food and Agriculture Organization (FAO): Rome, Italy; United Nations Environment Programme (UNEP): Nairobi, Kenya; Centre for Development and Environment (CDE), University of Berne: Berne, Switzerland, 2007.

6. Schwilch, G.; Bachmann, F.; Liniger, H.P. Appraising and selecting conservation measures to mitigate desertification and land degradation based on stakeholder participation and global best practices. Land Degrad. Dev. 2009, 20, 308-326.

7. United Nations University (UNU-INWEH). Guidelines for the Preparations and Reporting on Globally Relevant SLM Impact Indicators for Project Level Monitoring; UNU-INWEH: Hamilton, ON, Canada, 2011.

8. Schwilch, G., Hessel, R., Verzandvoort, S., Eds. Desire for Greener Land. Options for Sustainable Land Management in Drylands; Centre for Development and Environment, University of Bern (CDE): Bern, Switzerland; ALTERRA-Wageningen UR, World Soil Information (ISRIC) and Technical Centre for Agriculture and Rural Cooperation (CTA): Wageningen, The Netherlands, 2012.

9. Moreno, A.; Pereira, L.S. As obras de engenharia rural e os seus impactos nos recursos hídricos em Cabo Verde; 7 a Silusba da APRH: Evora, Portugal, 2005.

10. Tavares, J.; Ferreira, A.J.D.; Reis, E.A.; Baptista, I.; Amoros, R.; Costa, L.; Furtado, A.M.; Coelho, C. Appraising and selecting strategies to combat and mitigate desertification based on stakeholder knowledge and global best practices in Cape Verde Archipelago. Land Degrad. Dev. 2013, 25, 45-57.

11. Langworthy, M.; Finan, T. Waiting for Rain: Agriculture and Ecological Imbalance in Cape Verde; Technology and Engineer Book; Lynne Rienner Publishers: Boulder, CO, USA, 1997; p. 212. 
12. Sanchez-Moreno, J.F.; Mannaerts, C.M.; Jetten, V. Influence of topography on rainfall variability in Santiago Island, Cape Verde. Int. J. Climatol. 2013, doi:10.1002/joc.3747.

13. Instituto Nacional de Gestão e Desenvolvimento dos Recursos Hídricos (INGRH). Plano de Acção Nacional para Gestão Integrada dos Recursos Hídricos-PAGIRE; INGRH Serie No 45, 2; República de Cabo Verde: Praia, Cape Verde, 2010.

14. Diniz, A.C.; Matos, G.S. Carta de Zonagem Agro-ecológica e de Vegetação de Cabo Verde: I-Ilha de Santiago. Garcia da Orta; Serie de Botânica 1986, 8, 39-82.

15. Instituto Nacional de Investigação e Desenvolvimento Agrário (INIDA). Manual de Fertilidade do solo e fertilização das culturas; Sociedade Astória, Lda: S. Jorge dos Órgãos, Cape Verde, 1997.

16. Instituto Nacional de Investigação e Desenvolvimento Agrário-Desertification Mitigation and Remediation of Land (INIDA-DESIRE). Characterization of the Ribeira Seca Watershed-Santiago Island-Cape Verde Hotspot; Field Guide for the DESIRE 2nd Plenary Meeting; INIDA-DESIRE: Praia, Cape Verde, 2008.

17. World Bank. World Development Report 2000/2001: Attacking Poverty; World Bank: Washington, DC, USA, 2000.

18. DESIRE Project-Harmonised Information System: Providing Local Solutions to Global Sustainable Land Management Problems. Available online: http://www.desire-his.eu (accessed on 1 June 2014).

19. World Overview of Conservation Approaches and Technologies (WOCAT). Questionnaires on SLM technologies and approaches (basic). In A Framework for the Evaluation of Sustainable Land Management (Revised); Liniger, H.P., Schwilch, G., Meckdachi Studer, R., Hauert, C., van Lynden, G., Critchley, W., Eds.; Centre for Development and Environment, Institute of Geography, University of Berne: Berne, Switzerland, 2008.

20. World Overview of Conservation Approaches and Technologies (WOCAT). Available online: http://www.wocat.net (accessed on 1 June 2014).

21. Aerial Photography and Imagery, Ortho-Corrected-2010 Digital Orthophotos-Lafayette County; Aerial Data Service, Inc.: Tulsa, OK, USA, 2010.

22. Schwilch, G.; Bestelmeyer, B.; Bunning, S.; Critchley, W.; Herrick, J.; Kellner, K.; Liniger, H.P.; Nachtergaele, F.; Ritsema, C.J.; Schuster, B.; et al. Experiences in monitoring and assessment of sustainable land management. Land Degrad. Dev. 2011, 22, 214-225.

23. Lesourd, M. État et société aux îles du Cap-Vert. Collection «Hommes et Sociétés»; Éditions Karthala: Paris, France, 1995; p. 524.

24. Amaral, I. Santiago de Cabo Verde: A terra e os Homens; Memórias da Junta de Investigação do Ultramar, segunda série, n²8; Universidade do Algarve: Faro, Portugal, 2007; p. 444.

25. Haagsma, B.; Reij, C. Frentes de trabalho: Potentials and limitations of large scale labour employment for soil and water conservation in Cape Verde. Land Degrad. Dev. 1993, 4, 73-85.

26. Querido, A.L. Watershed System Analysis for Evaluating the Efficiency of Soil and Water Conservation Works: A Case Study in Ribeira Seca, Santiago Island, Cape Verde; Faculty of Geo-Information Science and Earth Observation, University of Twente (ITC): Enschede, The Netherlands, 1999.

27. National Adaptation Programme of Action on Climate Change (NAPA 2008-2012); Global Environmental Fund/United Nations Development Programme (GEF/UNDP): Praia, Cape Verde, 2007.

28. Pretty, J. Participatory learning for sustainable agriculture. World Dev. 1995, 23, 1247-1263. 
29. Reed, M.S. Stakeholder participation for environmental management: A literature review. Biol. Conserv. 2008, 141, 2417-2431.

30. Mutekanga, F.P.; Kessler, A.; Leber, K.; Visser, S. The use of stakeholders' analysis in integrated watershed management. Mt. Res. Dev. 2013, 33, 122-131.

31. Reed, M.S.; Fraser, E.D.G.; Morse, S.; Dougill, A.J. Integrating methods for developing sustainability indicators that can facilitate learning and action. Ecol. Soc. 2005, 10, r3.

32. Reed, M.S.; Buenemann, M.; Atlhopheng, J.; Akhtar-Schuster, M.; Bachmann, F.; Bastin, G.; Bigas, H.; Chanda, R.; Dougill, A.J.; Essahli, W.; et al. Cross-scale monitoring and assessment of land degradation and sustainable land management: A methodological framework for knowledge management. Land Degrad. Dev. 2011, 22, 261-271.

33. Stringer, L.C.; Reed, M.S. Land degradation assessment in Southern Africa: Integrating local and scientific knowledge bases. Land Degrad. Dev. 2007, 18, 99-116.

34. Schwilch, G.; Bachmann, F.; de Graaff, J. Decision support for selecting SLM technologies with stakeholders. Appl. Geogr. 2012, 34, 86-98.

35. The Committee for Development Policy, Development Policy and Analysis Division, United Nations. Monitoring the progress of graduated countries - Cape Verde. In Proceedings of Expert Group Meeting for Review of the List of the Least Developed Countries, New York, NY, USA, 16-17 January 2011; CDP2012/PLEN/11.

36. Tavares, J.; Amiotte-Suchet, P. Rainfall erosion risk mapping in volcanic soils of Santiago Island, Cape Verde Archipelago. Afr. Geosci. Rev. 2007, 14, 399-414.

37. Baptista, I.; Ritsema, C.J.; Querido, A.; Ferreira, A.D.F; Geissen, V. Improving rainwater-use in Cape Verde drylands by reducing runoff and erosion. Geoderma 2015, 237-238, 283-297.

38. Barry, O.; Smolikowski, B.; Roose, E. Bilan de la lutte anti-érosive dans les zones d'agriculture pluviale au Cap-Vert; un projet innovant, le PRODAP. Agric. Dév. CIRAD-CA 1995, 5, 57-68.

39. Lopes, V.; Mayer, J. Watershed management program on Santiago Island, Cape Verde. Environ. Manag. 1993, 17, 51-57.

40. Mannaerts, C.M. Contribution à l'évaluation de l'érosion des sols au Cap Vert; Rapport Inédit; GCP/CVI/002/BEL.FAO; Food and Agriculture Organization (FAO): Rome, Italy, 1986; p. 43.

41. Mannaerts, C.M. Assessment of the Transferability of Laboratory Rainfall-Runoff and Rainfall-Soil Loss Relationship to Field and Catchment Scales: A Study in the Cape Verde Islands. Ph.D. Thesis, University of Twente, Enschede, The Netherlands, 1993.

42. Tavares, J. Soil Erosion in Cape Verde: A Study of Processes and Quantification at the Scale of Three Watersheds of the Santiago Island. Ph.D. Thesis, Bourgogne University, Dijon, France, 2010.

43. Sabino, A. As estruturas de conservação do solo e água em Cabo Verde e a quantificação dos impactos na área do Watershed Development Project (Ilha de Santiago). In Proceedings of the 1as Jornadas sobre Agricultura de Cabo Verde, Comunicações do Instituto de Investigação Científica Tropical, Série de Ciências Agrárias, Lisboa, Portugal, 23-25 October 1990; pp. 91-124.

44. Wakindiki, C.; Ben-Hur, M. Indigenous soil and water conservation techniques: Effects on runoff, erosion, and crop yields under semi-arid conditions. Aust. J. Soil Res. 2004, 40, 367-379. 
45. Liniger, H.P.; Mekdaschi Studer, R.; Hauert, C.; Gurtner, M. Sustainable Land Management in Practice - Guidelines and Best Practices for Sub-Saharan Africa; TerrAfrica: Halfway House Midrand, South Africa; World Overview of Conservation Approaches and Technologies (WOCAT): Berne, Switzerland; Food and Agriculture Organization of the United Nations (FAO): Rome, Italy, 2011.

46. Direcção Geral de Agricultura, Silvicultura e Pecuária (DGASP). Inventario Florestal Nacional; DGASP: Praia, Cape Verde, 2013.

47. World Overview of Conservation Approaches and Technologies (WOCAT)/Land Degradation Assessment in Drylands (LADA)/Desertification Mitigation and Remediation of Land (DESIRE). A Questionnaire for Mapping Land Degradation and Sustainable Land Management; Liniger, H.P., van Lynden, G., Nachtergaele, F., Schwilch, G., Eds.; Centre for Development and Environment, Institute of Geography, University of Berne: Berne, Switzerland, 2008.

48. Desertification Mitigation and Remediation of Land (DESIRE). Pesera Model Simulation for Ribeira Seca Watershed; DESIRE Scientific Report Series (WP 5.3); University of Leeds: Leeds, UK, 2011.

49. Instituto Nacional de Investigação e Desenvolvimento Agrário (INIDA). Avaliação da produtividade das culturas de sequeiro; Relatório do estudo realizado pelo INIDA para o Agriculture Cooperative Development International ACDI/VOCA; INIDA: São Jorge, Cape Verde, 2006.

50. Varela, A.C. Avaliação do impacto das técnicas de conservação de solo e água na produção agrícola pluvial e na qualidade do solo: Estudo de caso da bacia hidrográfica da Ribeira Seca, Santiago. Master's Thesis, Universidade de Cabo Verde/Universidade Técnica de Lisboa (UniCV/ISA-UTL), Praia, Cape Verde, 2012.

51. Ministério de Desenvolvimento Rural (MDR). Diagnóstico da implementação dos instrumentos: Plano Estratégico de Desenvolvimento Agrícola-Plano Nacional de Investimento Agrícola (PEDA-PNIA): Praia, Cape Verde, 2012.

52. Department for International Development (DFID). Sustainable Livelihood Guidance Sheets. 1999. Available online: http://www.livelihoods.org (accessed on 1 June 2014).

53. Instituto Nacional de Investigação e Desenvolvimento Agrário (INIDA). Avaliação económica de 4 explorações agrícolas em Santiago; Relatório de actividades; INIDA: São Jorge dos Órgãos, Cape Verde, 2013.

54. Food and Agriculture Organization of the United Nations (FAO). The State of Food and Agriculture: Paying Farmers for Environmental Services; FAO: Rome, Italy, 2007.

55. Food and Agriculture Organization of the United Nations (FAO). The State of the World's Land and Water Resources for Food and Agriculture: Managing Systems at Risk; FAO: Rome, Italy; Earthscan: London, UK, 2011.

(C) 2015 by the authors; licensee MDPI, Basel, Switzerland. This article is an open access article distributed under the terms and conditions of the Creative Commons Attribution license (http://creativecommons.org/licenses/by/4.0/). 